UDK: 636.7.09:616-006-074

Research article

DOI: 10.2478 /acve-2019-0024

\title{
IMMUNOHISTOCHEMICAL DISTINGUISHING BETWEEN CANINE PERIPHERAL NERVE SHEATH TUMORS AND PERIVASCULAR WALL TUMORS
}

\author{
VUČIĆEVIĆ Ivana ${ }^{1 *}$, MARINKOVIĆ Darko ${ }^{1}$, KUKOLJ Vladimir ${ }^{1}$, NEŠIĆ Slađan ${ }^{1}$, \\ ANIČIĆ Milan ${ }^{1}$, ĐURĐEVIĆ Biljana ${ }^{2}$, ALEKSIĆ-KOVAČEVIĆ Sanja ${ }^{1}$ \\ ${ }^{1}$ Department of Pathology, Faculty of Veterinary Medicine, University of Belgrade, Belgrade, Serbia; \\ ${ }^{2}$ Scientific Veterinary Institute "Novi Sad”, Novi Sad, Serbia
}

(Received 13 May, Accepted 27 July 2019)

Peripheral nerve sheath tumors (PNSTs) comprise a heterogeneous group of neoplasms originating from the elements of the nerve sheath. They are divided into two forms: benign and malignant PNST. Both benign and malignant PNSTs are not very common in domestic animals but they are reported in different animal species. Histologically, PNSTs are composed predominantly of spindle cells arranged in bundles, whorls and sheets, with a different number of pleomorphic cells and mitotic figures.

The aim of this study was a reclassification of $17 \mathrm{dog}$ tumor samples initially diagnosed with peripheral nerve sheath tumors using histopathological analysis. The main criterion for reclassification was immunohistochemical positivity for various antigens.

PNSTs are often histologically very similar to other spindle cell tumors and immunohistochemistry is required for differential diagnosis. PNSTs generally express vimentin, S-100 protein, glial fibrillary acidic protein (GFAP), collagen IV and laminin.

Four tumor samples were positive to muscular marker $\alpha$-SMA and vimentin and negative for S-100 protein and desmin. The spindle cells whirling around some blood vessels were observed in these tumors so they were reclassified as perivascular wall tumors (PWTs). The other 13 tumors were S-100 protein and vimentin positive and $\alpha$-SMA and desmin negative, thus classified as PNST.

The use of the immunohistochemical panel is necessary for distinguishing PNSTs from PWTs in routine diagnostics.

Key words: canine, immunohistochemistry, peripheral nerve sheath tumors

\section{INTRODUCTION}

Peripheral nerve sheath tumors (PNSTs) comprise a heterogeneous group of neoplasms originating from the elements of the nerve sheath, such as Schwann cells,

*Corresponding author: e-mail: ivucicevic@gmail.com 
perineural cells and intraneural fibroblasts. Generally, the term schwannoma presents a tumor composed solely of cells originated from Schwann cells, while neurofibroma/ sarcoma is composed of Schwann cells and perineural cells [1,2]. According to morphologic features and biologic behavior, PNSTs are divided into two forms: benign PNST (BPNST) and malignant PNST (MPNST) [3]. Generally, BPNSTs are not very common in domestic animals but they are reported in different animal species, such as cat, horse, pig and goat [4-7] and most frequently are seen in dogs and cattle $[8,9]$. Likewise, MPNSTs are rare in animals and in dogs, they account for $27 \%$ of all nervous system tumors $[1,10]$. Middle-aged or older animals are more predisposed to develop PNSTs [2,11].

Histologically, benign tumors of peripheral nerve sheath are usually well circumscribed, encapsulated and composed predominantly of spindle cells arranged in bundles and sheets [12]. The slightly polymorphic neoplastic cells could be separated by a collagenous matrix and form concentric whorls (Antoni type A pattern) or the cellular density could be reduced and cells surrounded by loose fibrous to mucinous stroma (Antoni type B pattern) [13,14]. The double row of palisading tumor cells, known as Verocay bodies, is rarely observed [15].

Microscopically, malignant tumors of peripheral nerve sheath are non-encapsulated and consist of usually highly pleomorphic cells with numerous mitotic figures $[12,13]$. Neoplastic cells are arranged in fascicles, whorls or sheets and embedded in a fibrillar collagenous stroma. MPNSTs have an infiltrative growth pattern and metastasize to distant organs $[13,14]$. Areas of glandular, rhabdomyoblastic squamous, cartilaginous or osteoid differentiation may be seen occasionally $[12,13]$.

PNSTs generally express vimentin, S-100 protein, glial fibrillary acidic protein (GFAP), collagen IV and laminin. Unlike BPNSTs, malignant forms of PNST are usually S-100 protein negative $[11,16]$. Immunohistochemical staining is very important since PNSTs are often histologically very similar to other sarcomas and distinguishing these tumors from other soft tissue tumors, especially perivascular wall tumors could be difficult. Perivascular wall tumors (PWTs) are of mesenchymal origin and belong to soft tissue sarcomas arising from the components of the perivascular wall [17].

The aim of this study was reclassification of dog tumor samples initially diagnosed with PNST using histopathological analysis. The main criterion for the reclassification was immunohistochemical positivity for various antigens.

\section{MATERIALS AND METHODS}

A subset of 17 dogs from the Department of Pathology medical database was searched for diagnoses of peripheral nerve sheath tumors. Follow-up data including age, sex, breed, and location of the mass, were obtained from referring veterinarians.

Formalin-fixed paraffin embedded tissue samples were cut on $5 \mu \mathrm{m}$ sections and the three-step indirect immunohistochemical (IHC) technique was performed. Antigen 
retrieval was achieved by heating the sections in a microwave oven at $560 \mathrm{~W}$ for 21 minutes in a citrate buffer ( $\mathrm{pH}$ 6.0). The sections were treated with methanol containing $0.3 \%$ hydrogen peroxide for 15 minutes at room temperature $\left(22 \pm 3^{\circ} \mathrm{C}\right)$ in order to inactivate endogenous peroxidase. Nonspecific binding of secondary antibodies was minimized by incubating with 50\% normal goat serum in PBS for $20 \mathrm{~min}$. After antigen retrieval and inactivation of endogenous peroxidase, the sections were incubated with primary antibodies (Table 1) diluted in phosphate buffer saline ( $\mathrm{pH} 7.2)$ for $1 \mathrm{~h}$ in a humid chamber at room temperature $\left(22 \pm 3^{\circ} \mathrm{C}\right)$. A streptavidin-immunoperoxidase staining procedure (Dako) was used for immunolabeling. The immunoreaction was visualized with $\mathrm{DAB}+$ (3,3'-diaminobenzidine tetrahydrochloride, DAKO, K3468). Sections were counterstained with Mayer's hematoxylin. Aqueous medium glycergel (DAKO, C563) was used on the stained sections for mounting. Appropriate positive and negative controls were used. Known canine PNST was used as positive control while negative controls were obtained by replacing the primary antibodies by a buffer.

Table 1. Primary antibodies used for immunohistochemical staining

\begin{tabular}{lcc}
\hline Antibody & Source & Dilution \\
\hline S-100 & Dako (Z0311) & $1: 400$ \\
$\alpha$-SMA & Dako (M0851) & $1: 50$ \\
Desmin & Dako (M0760) & $1: 100$ \\
Vimentin & Dako (N1583) & RA \\
GFAP & Dako (Z0334) & $1: 400$ \\
\hline
\end{tabular}

Tumors were evaluated according to Ko et al. (2014) [18] considering as positive tumors with immunolabeling in more than $10 \%$ of neoplastic cells.

Digital images were made using an optical microscope Olympus BX51 with digital camera Olympus Color View III. A reevaluation was made by two pathologists separately analyzing hematoxylin and eosin (HE) stained sections using a light microscope (BX51, Olympus Optical, Japan).

\section{RESULTS}

\section{Histopathology}

Histopathological examination of tissue samples revealed similar appearance between all tumors. PNST were composed of pleomorphic spindle cells, mostly arranged in interwoven bundles, fascicles, whorls and sheets embedded in a collagenous stroma. Neoplastic cells had small dark nuclei with prominent nucleoli and moderate mitotic activity. They showed marked anisokaryosis. Partly, the areas of low cellularity and abundant myxomatous stroma were present (Figure 1a). In some cases, neoplastic cells 
infiltrated surrounding tissue, accompanied by lymphocytes and plasma cells. PWTs were also composed of pleomorphic spindle cells with small amounts of eosinophilic cytoplasm arranged in interlacing bundles and concentric whorls separated by the collagenous stroma. Few of them had necrotic areas within the lesion. Mitotic figures were inconspicuous. The significant numbers of inflammatory cells (eosinophils and mast cells) were found around the small vessels (Figure 2a).
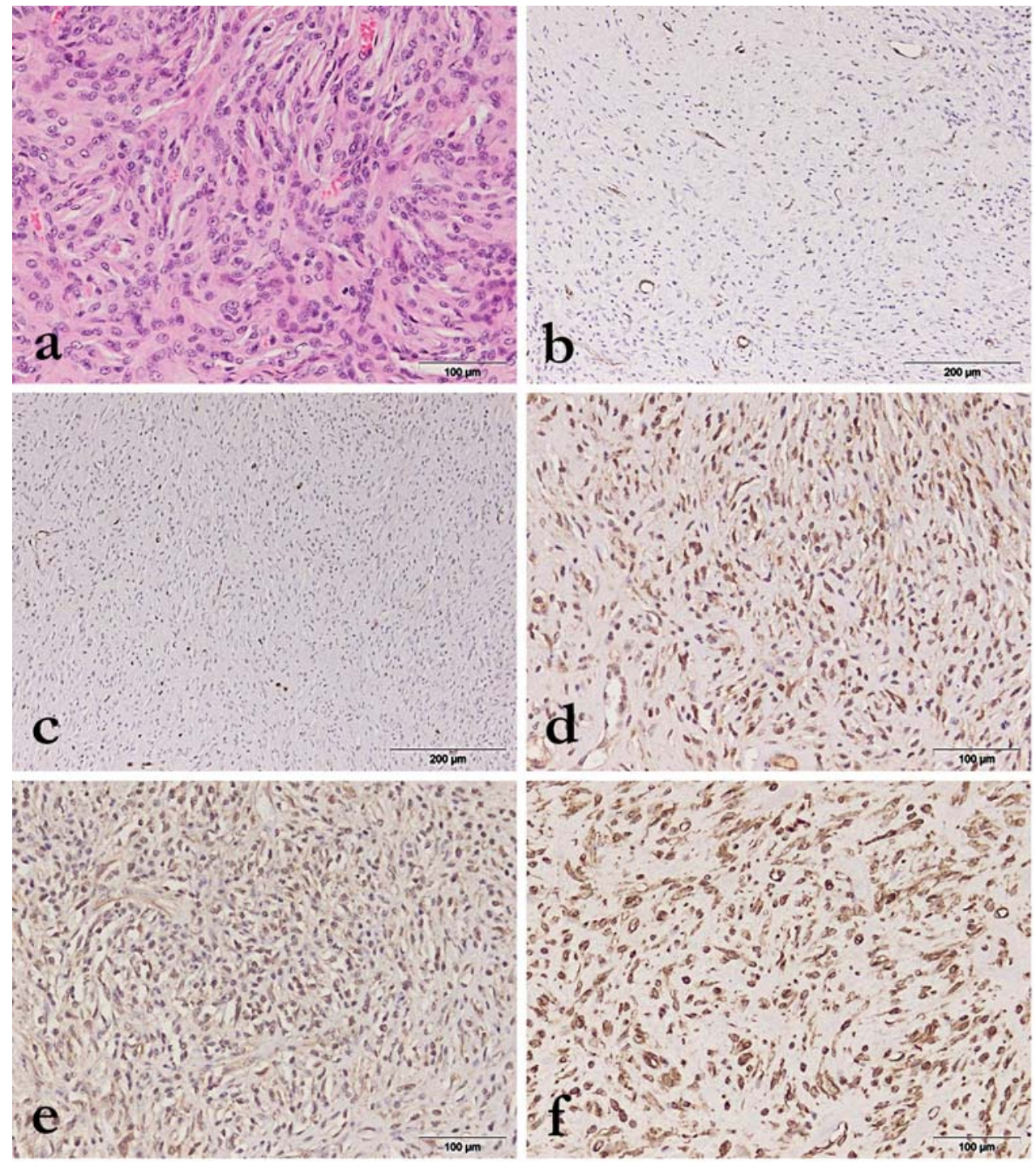

Figure 1. Histological and immunohistochemical characteristics of PNST. a) Pleomorphic spindle cells, mostly arranged in interwoven bundles with collagenous stroma and cells with prominent nucleoli and moderate mitotic activity, HE, b) Tumor cells negative for $\alpha$-SMA, c) Tumor cells negative for desmin, d) Tumor cells positive for S-100 protein, e) Tumor cells positive for GFAP, f) Tumor cells positive for vimentin. 

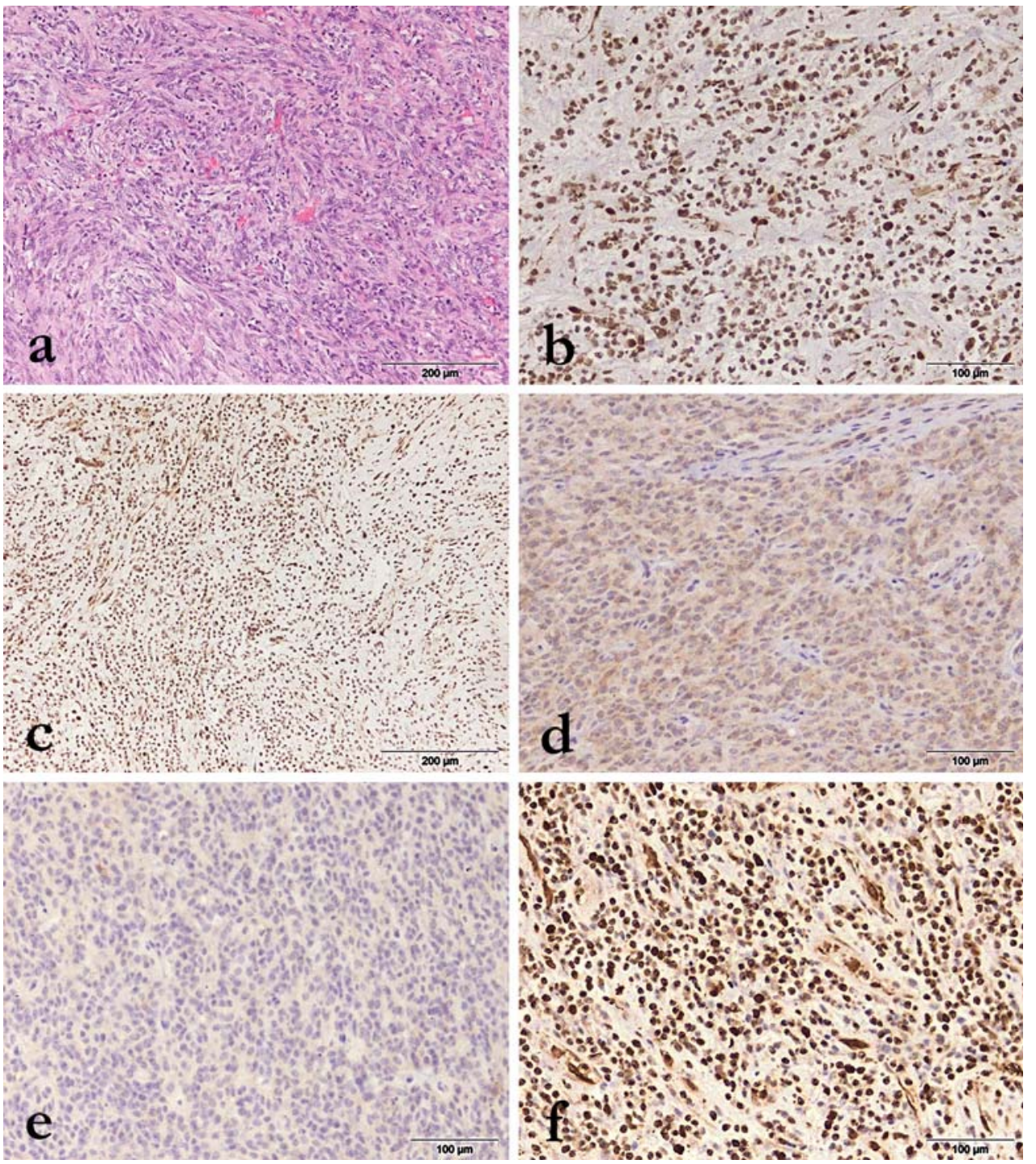

Figure 2. Histological and immunohistochemical characteristics of PWT. a) Pleomorphic spindle cells with small amounts of eosinophilic cytoplasm arranged in interlacing bundles and concentric whorls separated by the collagenous stroma, HE, b) Tumor cells positive for $\alpha$-SMA, c) Tumor cells positive for desmin, d) Tumor cells negative for S-100 protein, e) Tumor cells negative for GFAP, f) Tumor cells positive for vimentin.

\section{Immunohistochemistry}

Thirteen tumors $(76.47 \%)$ were negative for muscular markers such as $\alpha$-smooth muscle actin ( $\alpha$-SMA) (Figure 1b) and desmin (Figure 1c) and positive for S-100 protein (Figure 1d) and GFAP (Figure 1e). The other four tumors (23.53\%) demonstrated strong immunoreactivity for $\alpha$-SMA (both nuclear and cytoplasmic) (Figure 2b) and 
desmin (Figure 2c), but were negative for S-100 protein (Figure 2d) and GFAP (Figure 2e). All tumor samples had strong expression of vimentin (Figures $1 \mathrm{f}$ and $2 \mathrm{f}$ ).

Based on IHC results, the 13 tumors that had a positive reaction for neural marker S-100 protein remained classified as PNST, while the four cases negative for S-100 protein and positive for muscular markers were reclassified as PWT.

\section{DISCUSSION}

The similar microscopical appearance of peripheral nerve sheath tumors and perivascular wall tumors often hampers their specific differential diagnosis. In this study, histologically, PNSTs were composed of a dense population of spindle-shaped to oval cells arranged in fascicles, whorls or sheets. Partly, the areas of low cellularity and abundant myxomatous stroma were present. According to Gross et al., (2005) [13] PNSTs are characterized by well-defined cellular component (Antoni A pattern) and hypocellular areas with loose fibrous to myxoid stroma (Antoni B pattern).

The current diagnosis and differentiation of peripheral nerve sheath tumors are based mainly on their histological features. However, a histopathological examination may be sufficient for primary diagnosis, but it is usually necessary to perform an immunohistochemical analysis in order to distinct PNST from PW'T. Besides PWT, fibrosarcomas and amelanotic melanomas are often found to be of significance for the differential diagnosis [9].

In the current study, microscopical examination of these tumors revealed the presence of spindle cells with elongated nuclei arranged in interwoven bundles and fascicles embedded in the collagenous stroma with high cell pleomorphism and a moderate number of mitoses. Both Antoni A and Antoni B histological growth patterns were observed. A similar pattern was also reported by Chijiwa et al. (2004) [3] and Silva et al. (2017) [14]. The concentric whorls were present in PNSTs, but more often were observed in PWTs as neoplastic cells surrounding blood vessels rather than collagen fibers. Gaitero et al. (2008) [19] also noted that the concentric pattern in PNSTs was not as extensive as that occurring in PWTs.

To date, there is no immunohistochemical marker that is expressed exclusively by PNSTs [20]. The immunohistochemical analysis of the 17 tumor samples in this study showed positivity for S-100 protein and glial fibrillary acidic protein in 13 cases. Rodriguez et al. (2012) [21] emphasize that PNSTs typically show strong expression of S-100 protein, while GFAP is expressed in a subset of PNSTs. Since the expression of S-100 protein may be present in some other tumors, even in those of non-neuronal origin (such as synovial sarcomas, leiomyosarcomas, and rhabdomyosarcomas), it should not be considered as definite proof of PNST [3,21]. However, the lack of S-100 protein expression is described in some cases of canine MPNSTs $[3,19,20]$. It is explained by the fact that MPNSTs consist of several cell types and S-100 protein 
expression will be strong only in tumors consisting predominantly of Schwann cells and a smaller number of perineural cells and fibroblasts [22].

Alpha-smooth muscle actin, similarly as desmin can be found in cells of muscle origin and tumors originating from these cells. In our study 13 tumor samples of PNSTs were negative for both $\alpha$ - smooth muscle actin and desmin, while 4 tumors were positive for one or more muscular markers. Chijiwa et al. (2004) [3] published analogous results that none of PNSTs was positive for $\alpha$-smooth muscle actin, while 4 of 5 PWTs were positive for $\alpha$-SMA. Although the $\alpha$-SMA positive cells have not been described in benign PNSTs, neoplastic cells with $\alpha$-SMA expression were observed in malignant PNST in the rat [23]. Unlikely PNST, expression of $\alpha$-SMA is widely presented in tumor cells of PWT [24].

Vimentin is an intermediate filament of mesenchymal cells, so all tumors of mesenchymal origin show positive staining. In this study, all tumor samples were positive for vimentin. That PNSTs are generally positive for vimentin, revealed also Chijiwa et al., 2004 [3] in which study all 100\% of examined tumors were vimentinpositive, as well as Teixeira et al. 2016 [20] with 95\% positive cases, but with different expression intensity between the benign and the malignant cases. Negative vimentin staining was observed in MPNSTs very rarely and that could be explained by very low differentiation of malignant cells [9].

The patohistological analysis is essential but not sufficient for the differential diagnosis of PNST and tumors such as fibrosarcomas, PWTs and amelanotic melanomas. In agreement with previous manuscripts, the conclusion is that using of an immunohistochemical panel for distinguishing PNSTs from PWTs is necessary.

\section{Authors' contributions}

VI drafted the manuscript, carried out literature research, carried out pathohistological and the immunohistochemical examination took photography and translated the manuscript. MD participated in the design of the study, participated in the pathohistological and immunohistochemical examination. KV participated in the pathohistological and immunohistochemical examination and technical support. NS participated in pathohistological and immunohistochemical examination and analysed data. AM participated in pathohistological and immunohistochemical examination and in the manuscript translation revision. BB participated in pathohistological and immunohistochemical examination and in the manuscript translation revision took photography. AKS has been involved in study design, drafting the manuscript and revising it critically and has given final approval of the version to be published. All authors read and approved the final manuscript. 


\section{Declaration of conflicting interests}

The author(s) declared no potential conflicts of interest with respect to the research, authorship, and/or publication of this article.

\section{REFERENCES}

1. Suzuki S, Uchida K, Nakayama H: The effects of tumor location on diagnostic criteria for canine malignant nerve sheath tumors (MPNSTs) and the markers for distinction between canine MPNSTs and canine perivascular wall tumors. Vet Pathol 2014, 51:722-736.

2. Hendrick MJ: Tumors of the nervous system. In: Meuten DJ, ed. Tumors in Domestic Animals. 5th ed. Ames, IA: Wiley Blackwell; 2017: 155-157.

3. Chijiwa K, Uchida K, Tateyama S: Immunohistochemical evaluation of canine peripheral nerve sheath tumors and other soft tissue sarcomas. Vet Pathol 2004, 41(4):307-318.

4. Ramires GA, Herraez P, Rodrigues F, Godhino A, Andrada M, Espinosa de los Monteros A: Malignant peripheral nerve sheath tumor (malignant Schwannoma) in the diaphragm of a goat. J Comp Pathol 2007, 137:137-141.

5. Schulman FY, Johnson TO, Facemire PR: Feline peripheral nerve sheath tumors: histologic, immunohistochemical, and clinicopathologic correlation (59 tumors in 53 cats). Vet Pathol 2009, 46(6):1166-1180.

6. Kegler K, Mundle K, Walliser U, Wohsein P: Primary intraparotid peripheral nerve sheath tumour with characteristics of benign Schwannoma in a horse. J Comp Pathol 2014, 150:382-387.

7. Resende TP, Pereira CER, Vannucci FA, Araujo FS, Santos JL, Cassali GD, Damasceno KA, Guedes RM: Malignant peripheral nerve sheath tumor in a sow. Acta Vet Scandinavica 2015, 57:56-59.

8. Ahmadi N, Oryan A, Ghane M, Daneshbod Y: Cutaneous schwannoma in a cow. Braz J Vet Pathol 2012, 5:81-85.

9. Boos GS, Bassuino DM, Wurster F, Castro NB, Watanabe TN, Silva GS, Sonne L and Driemeier D: Retrospective canine skin peripheral nerve sheath tumors data with emphasis on histologic, immunohistochemical and prognostic factors. Pesq Vet Bras 2015, 35(12):965974.

10. LeCouteur RA,Withrow SJ: Tumors of the nervous system. In: Small Animal Clinical Oncology, $4^{\text {th }}$ Edit., SJ Withrow, EG MacEwen, Eds. Saunders, St Louis, 2007: pp. 659-685.

11. Koestner A, Higgins RJ: Tumors of the nervous system. In: Tumors in Domestic Animals, 4th Edit., DJ Meuten, Ed., Iowa State Press, Ames, 2002: 697-738.

12. Koestner A, Bilzer T, Fatzer R, Schulman FY, Summers BA, Van Winkle TJ: Histological classification of tumors of the nervous system of domestic animals. Schulman FY, editor. WHO, Armed Forces Institute of Pathology, American Registry of Pathology; Washington, D.C, 1999: 37-38.

13. Gross TL, Ihrke PJ, Walder EJ, Affolter VK: Neural and Perineural Tumors. In: Skin Diseases of the Dog and Cat. Oxford, United Kingdom: Blackwell Science Ltd, 2005: 786-796. 
14. Silva EO, Goiozo PFI, Pereira LG, Headley SA and Bracarense AFRL: Concomitant malignant pulmonary peripheral nerve sheath tumour and benign cutaneous peripheral nerve sheath tumour in a dog. J Comp Path 2017, 157:46-50.

15. Sirri R, Sabattini S, Bettini G, Mandrioli L: Reclassification of 21 presumptive canine peripheral nerve sheath tumors (PNST) using a literature-based immunohistochemical panel. Acta Vet-Beograd 2016, 66(4):455-465.

16. Pumarola M, Anor S, Borras D, Ferrer I: Malignant epithelioid schwannoma affecting the trigeminal nerve of a dog. Vet Pathol 1996, 33:434-436.

17. Avallone G, Boracchi P, Caniatti M, Stefanello D, Ferrari R, Rebughini A, Roccabianca P: Canine Perivascular Wall Tumors: High Prognostic Impact of Site, Depth, and Completeness of Margins. Veterinary Pathology 2014, 51(4):713-721.

18. Ko SB, Song KO, Kang SC, Kim JH: Cutaneous peripheral nerve sheath tumors in 15 dogs. Korean J Vet Res 2014, 54:7-12.

19. Gaitero L, Añor S, Fondevila D, Pumarola M: Canine cutaneous spindle cell tumours with features of peripheral nerve sheath tumours: a histopathological and immunohistochemical study. J Comp Pathol 2008, 139(1):16-23.

20. Teixeira S, Amorim I, Rêma A, Faria F, Gärtner F: Molecular heterogeneity of canine cutaneous peripheral nerve sheath tumors: a drawback in the diagnosis refinement. In vivo 2016, 30:819-828.

21. Rodriguez FJ, Folpe AL, Giannini C, Perry A: Pathology of peripheral nerve sheath tumors: diagnostic overview and update on selected diagnostic problems. Acta Neuropathol 2012, 123:295-319.

22. Takeuchi A, Ushigome S: Diverse differentiation in malignant peripheral nerve sheath tumours associated with neurofibromatosis-1: an immunohistochemical and ultrastructural study. Histopathol 2001, 39:298-309.

23. Satoh H, Shimoda H, Daa T, Kashima K, Yokoyama S, Nakayama I: Establishment and immunohistochemical characterization of an experimentally induced transplantable malignant schwannoma in the rat and two derived cell lines. Acta Pathol Jpn 1993, 43:53744.

24. Avallone G, Helmbold P, Caniatti M, Stefanello D, Navak RC, Roccabianca P: The spectrum of canine cutaneous perivascular wall tumors: morphologic, phenotypic and clinical characterization. Vet Pathol 2007, 44:607-620.

\title{
RAZLIKOVANJE TUMORA OVOJNICA PERIFERNIH NERAVA I PERIVASKULARNIH TUMORA KOD PASA UPOTREBOM IMUNOHISTOHEMIJSKE METODE
}

\author{
VUČIĆEVIĆ Ivana, MARINKOVIĆ Darko, KUKOLJ Vladimir, NEŠIĆ Slađan, \\ ANIČIĆ Milan, ĐURĐEVIĆ Biljana, ALEKSIĆ-KOVAČEVIĆ Sanja
}

Tumori ovojnica perifernih nerava predstavljaju raznoliku grupu neoplazmi koje vode poreklo od ćelija koje obavijaju nerve. Podeljeni su u dve forme: benigni i maligni tumori ovojnica perifernih nerava. Iako nisu česti kod domaćih životinja, opisani su 
kod različitih životinjskih vrsta. Histološki, ovi tumori se sastoje dominantno od vretenastih ćelija koje formiraju snopove, vrtloge i trake, sa različitim brojem pleomorfnih ćelija i mitotskih figura.

Cilj ovog rada je reklasifikacija 17 uzoraka tumora pasa prvobitno histološki dijagnostikovanih kao tumori ovojnica perifernih nerava. Glavni kriterijum za reklasifikaciju bio je prisustvo imunohistohemijski pozitivne reakcije na različite antigene.

Tumori ovojnica perifernih nerava su često veoma slični drugim tumorima vretenastih ćelija i imunohistohemijsko bojenje je potrebno za diferencijalnu dijagnozu. Tumori ovojnica perifernih nerava uglavnom eksprimiraju vimentin, S-100 protein, kiseli glijalni fibrilarni protein, kolagen IV i laminin.

Od ispitanih tumora, četiri uzorka su bila pozitivna na mišićni marker $\alpha$-SMA i vimentin i negativna na S-100 i dezmin. U ovim tumorima mestimično su uočene vretenaste ćelije koje koncentrično okružuju pojedine krvne sudove, pa su oni reklasifikovani kao perivaskularni tumori. Ostalih 13 tumora su bili S-100 i vimentin pozitivni i $\alpha$-SMA i dezmin negativni i time klasifikovani kao tumori ovojnica prifernih nerava.

Upotreba imunohistohemijskog panela je neophodna za razlikovanje tumora ovojnica perifernih nerava od perivaskularnih tumora u rutinskoj dijagnostici. 